\title{
Study of supramolecular structure of petroleum asphaltenes
}

\author{
C Talgat I. Sharipov, ${ }^{1}$ Rauf Z. Bakhtizin, ${ }^{1}$ Svetlana A. Shutkova, ${ }^{3+}$ Mikhail Yu. Dolomatov, ${ }^{1,2}$ \\ Turlybek N. Nurakhmetov ${ }^{4}$ Zhussupbek M. Salikhodzha, ${ }^{4}$ and Bulat R. Badretdinov ${ }^{1}$ \\ ${ }^{1}$ Department of Physical Electronics and Nanophysics. Physical and technical Institute. \\ Bashkir State University. Z. Validi St., 32. Ufa, 450001. Bashkortostan Republic. Russia. \\ Phone:+7 (347) 229-96-47.E-mail: dolomatov@mail.ru \\ ${ }^{2}$ Department of Technology of Oil and Gas. Faculty of Technology. Ufa State oil Technical University. \\ Kosmonavtov St., 1. Ufa, 450062. The Republic Of Bashkortostan. Russia. \\ Phone:+7 (347) 243-15-35.E-mail: dolomatov@mail.ru \\ ${ }^{3}$ Department of Power Engineering and Physical. The Faculty of Energy Engineering. \\ Bashkir State Agrarian University. 50th anniversary of October St., 34. Ufa. 450001. \\ Bashkortostan Republic.Russia.Phone: +7 (347) 228-52-00.E-mail: Svetlana-Shutkova@yandex.ru \\ ${ }^{4}$ Department of Technical Physics. Eurasian National University of L.N. Gumilev, Kazakhstan. \\ Satbayev St. 2. Astana, 010008. Kazakhstan.Phone: +7 7172-65-32-29.E-mail: nurakhmetov_tn@enu.kz
}

*Supervising author; ${ }^{+}$Corresponding author Keywords: oil asphaltenes, nanoclusters, molecular mechanics method, ionization potential, electron affinity, atomic force microscopy.

\section{Abstract}

The article is devoted to the topical problem of studying the supramolecular structure of petroleum asphaltenes. They are the prospective materials for molecular electronics and nanotechnology. At present, the properties of asphaltenes at the supramolecular level are studied by various experimental methods and methods of mathematical modeling.

As objects of a research the asphaltenes concentrated in residual fractions of vacuum distillation of the West Siberian oil with a temperature of boiling more than $500{ }^{\circ} \mathrm{C}$ were used. Asphaltenes of samples allocated with dissolution of fractions in toluene with the subsequent sedimentation by surplus of $n$-heptane by Golde's technique. Results of ASM-researches show existence of steady units from nanoclusters of oil asphaltenes in the form of structures of an ellipsoidal form about $4.5 \mathrm{~nm}$ high and with a lateral size up to $100 \mathrm{~nm}$.

The research of supramolecular structure of nanoclusters of oil asphaltenes in the GAUSSIAN software package is executed. Calculation was carried out by method of molecular mechanics of MM with full optimization of geometry. The structure of molecular fragments of a nanoparticle of asphaltenes is defined according to data of ${ }^{1} \mathrm{H},{ }^{13} \mathrm{C}$ NMR and IR of spectroscopy and the chemical analysis earlier. These data will be agreed with results of works on identification of molecules of asphaltenes by the ASM method of high resolution. Follows from calculations that the nanoclusters having an appearance of quasicrystal reniform structures with number of molecular fragments from 2 to 10 are steadiest, at the same time the distance between the planes of molecular fragments of a nanocluster is in the range from 3.53 up to $3.67 \AA$, and diameter of particles 11-40 $\AA$. Data on height of nanoclusters will well be agreed with results of ASMresearches for small structures. Calculations of supramolecular structure of oil asphaltenes by method of molecular mechanics show considerable energy of intermolecular interaction of structural molecular fragments of $60-118 \mathrm{~kJ} / \mathrm{mol}$ that testifies to a possibility of self-assembly of ordered structures from these nanoparticles visualized by means of ASM. The received results are confirmed by data of the X-ray diffraction analysis and electric measurements on energy of activation of hopping conductivity $(129.58 \mathrm{~kJ} / \mathrm{mol})$ and also the carried-out earlier thermodynamic calculations. As appears from calculations, the increased stability of quasicrystal structure which arises, most likely, as a result of transfer of a charge between fragments as molecules have the low potential of ionization and high affinity to an electron is characteristic of nanoclusters.

\section{References}

[1] M.Yu. Dolomatov, S.A. Shutkova, S.V. Dezortsev. Structure of molecular nanoparticles of petroleum asphaltenes. Journal of Structural Chemistry. 2012. Vol.53. No.3. P.569-573. (russian)

[2] S.A. Shutkova, M.Yu. Dolomatov, M.M. Dolomatova. Structural and chemical characteristics of model molecular fragments of oil petroleum resins. Journal of Structural Chemistry. 2018. No.3. P.573-578. (russian)

Kazan. The Republic of Tatarstan. Russia.

(c) Butlerov Communications. 2019. Vol.57. No.3. 
[3] M.Y. Dolomatov, A.M. Petrov, R.Z. Bakhtizin. Features of temperature dependence of electrical conductivity in multicomponent organic spin glasses. Inorganic Materials: Applied Research. 2016. No.7. P.453-457.

[4] Yu.V. Korzhov, S.A. Orlov. Aggregation and coagulation of asphaltenes in an oil film: physical characteristics of products of superficial deposits. Izvestiya Tomsk Polytechnic University. Engineering of Georesources. 2016. Vol.327. No.12. P.62-74. (russian)

[5] T.I. Sharipov, M.Yu. Dolomatov and R.Z. Bakhtizin. The study of supramolecular structure of asphaltenes by atomic force microscopy. IOP Conf. Series: Materials Science and Engineering 443 (2018) 012028. doi:10.1088/1757-899X/443/1/012028

[6] Valter Antonio M. Branco, G. Ali Mansoori, Luiza Cristina De Almeida Xavier, Sang J. Park, Hussain Manafi. Asphaltene flocculation and collapse from petroleum fluid. Journal of Petroleum Science and Engineering 32 (2001) P.217-230.

[7] B. Schuler, G. Meyer, D. Pena, O.C. Mullins, L. Gross. Unraveling the Molecular Structures of Asphaltenes by Atomic Force Microscopy. Journal of the American Chemical Society. 2015. Vol.137 No.31. P.9870-9876.

[8] K. Akbarzade, A. Hammani, A. Harat, Ch. Dan, S. Allekson, K. Jefferson, Sh. Kabir, J. Marshall, R. Rogers, O. Malliks, T. Solbakken, etc. Asphaltenes of a problem and prospect. Oil and gas review. Moscow: Edition of the Schlumberger (Shlumberger) company. 2007. Vol.19. No.2. P.28-42. (russian)

[9] A.B. Marushkin, M.Yu. Dolomatov, R.N. Gimayev, N.M. Seliverstov. Thermodynamics of formation of supramolecular structure of asphaltenes. Chemistry of Solid Fuel. 1985. No.6. P.83-86. (russian)

[1] A.R. Hortal, B. Martinez-Haya, M.D. Lobato, J.M. Pedrosa, S. Lago. On the determination of molecular weight distributions of asphaltenes and their aggregates in laser desorption ionization experiments. J. Mass Spectrom. 2006. Vol.41. No.7. P.960-968.

[2] N.V. Lisitza, D.E. Freed, P.N. Sen, Y.Q. Song. Study of asphaltene nanoaggregation by nuclear magnetic resonance (NMR). Energy Fuels. 2009. Vol.23. No.3. P.1189-1193. 